\section{Earthworms and Seeds}

EARTHWORMS move seeds ${ }^{1,2}$ and viable seeds have been reported in worm casts ${ }^{3,4}$. The causes of loss of seeds from the soil are seldom identified ${ }^{5,6}$.

In our first experiment fourteen plant species were selected to provide a range of sizes and shapes of seed (Table 1). Petri dishes were prepared with filter paper to which was added $6 \mathrm{ml}$. of deionized water and the seeds. One specimen of Lumbricus terrestris (minimum fresh weight $3 \mathrm{~g}$ ) was introduced into each dish. The dishes were kept in darkness at laboratory temperatures for $18 \mathrm{~h}$, after which the worms were transferred to fresh dishes, and the seeds remaining in the original dishes counted. After a further $72 \mathrm{~h}$ the seeds in casts were recovered and counted.

Table 1 Fate of the Seeds of the Fourteen Species

Percentage of Percentage of Percentage of offered seed ingested seeds ingested seeds ingested by recovered not

L. terrestris from cast recovered

$\begin{array}{lcrr}\text { Poa annua } \text { L. } & 60 & 28.3 & 71.7 \\ \text { Agrostis tenuis } \text { Sibth. } & 50 & 0.0 & 100.0 \\ \text { Poa trivialis } \text { L. } & 40 & 41.0 & 59.0 \\ \text { Digitalis purpurea } \text { L. } & 32 & 53.1 & 46.9 \\ \text { Bellis perennis } \text { L. } & 17 & 58.8 & 41.2 \\ \text { Trifolium repens } \text { L. } & 16 & 62.5 & 37.5 \\ \text { T. pratense } \text { L. } & 15.5 & 48.3 & 51.7 \\ \text { T. } \text { incarnatum } \text { L. } & 13 & 65.0 & 35.0 \\ \text { Dactylis glomerata } \text { L. } & 10 & 80.0 & 20.0 \\ \text { Trifolium striatum } \text { L. } & 7.5 & 66.7 & 33.3 \\ \text { Sinapis alba } \text { L. } & 6 & 66.7 & 33.3 \\ \text { Festuca pratensis } \text { Huds. } & 4 & 50.0 & 50.0 \\ \text { Lolium perenne } \text { L. } & 3 & 66.7 & 33.3 \\ \text { Spring barley } c v \text {. Deba } & & & \\ \text { abed. } & 0 & - & - \\ \end{array}$

Results are for twenty replicates, each of ten seeds, for each species.

L. terrestris ingested seeds, but there was wide variation between species, from $0 \%$ for barley to $60 \%$ for Poa annua (Table 1). None of the ingested grains of Agrostis tenuis and less than $50 \%$ of those of Poa annua and $P$. trivialis were recovered from the casts. Survival of seeds of other species was higher.

In a second experiment we studied the germination of seeds recovered from casts. The results show that some seeds can pass through the gut without losing their viability and that the final percentage germination was higher for such seeds than for seeds from the original stock (Table 2).

Table 2 Percentage Germination (12 Days after Sowing) of Three Seeds after Passage of Seeds through the Gut of $L$. terrestris

\begin{tabular}{lccc}
\hline \multicolumn{1}{c}{ Species } & \multicolumn{3}{c}{ Percentage germination } \\
Original & $\begin{array}{c}\text { After passage } \\
\text { stock }\end{array}$ & $\begin{array}{c}\text { L.S.D. } \\
\text { through gut }\end{array}$ & $(P=0.05)$ \\
Poa trivialis & 66.2 & 90.5 & 8.60 \\
$\begin{array}{l}\text { Bellis perennis } \\
\begin{array}{l}\text { Trifolium repens (non- } \\
\text { hard seed) }\end{array}\end{array}$ & 83.0 & 96.7 & 8.02 \\
$T$. repens (hard seed) & 74.7 & 82.0 & 8.67 \\
\hline
\end{tabular}

Results of three trials each with twenty replicates of ten seeds.
Viable seeds of many species have been recovered from worm casts by both flotation and direct germination tests.

M. MCRILL

G. R. SAGAR

School of Plant Biology,

University College of North Wales,

Bangor

Received March 26; revised April 4, 1973.

${ }^{1}$ Darwin, C. R., The Formation of Vegetable Mould through the Action of Worms with Observations on their Habits (John Murray, London, 1881).

${ }^{2}$ Gerard, B. M., Soil Organisms (edit. by Doeksen, J., and van der Drift, J.), 55 (North-Holland, 1963).

${ }^{3}$ Chippindale, H. G., and Milton, W. E. J., J. Agric. Sci, 22, 451 (1932).

${ }^{4}$ Milton, W. E. J., J. Ecol., 27, 149 (1939).

5 Roberts, H. A., Rep. Nat. Veg. Res. Stn 1969 (1970).

${ }^{6}$ Sagar, G. R., Proc. Tenth Brit. Weed Control Conf., 965 (1970).

\section{Intelligence and Handedness}

THE data of Levy ${ }^{1}$ have been quoted ${ }^{2,3}$ as evidence that people with left handed preferences have significantly lower visuospatial IQ than right handed people, although the verbal IQ's of the two groups does not differ. I have analysed data ${ }^{4}$ previously obtained and classified for other purposes, to see if they support Levy's conclusions (Table 1).

Table 1 Intelligence and Handedness: Comparison of Data from Two Sources 1,4

\begin{tabular}{|c|c|c|c|}
\hline & $\begin{array}{l}\text { Graduate } \\
\text { science students }\end{array}$ & \multicolumn{2}{|c|}{ Academic scientists ${ }^{4}$} \\
\hline $\begin{array}{l}\text { Numbers (handed- } \\
\text { ness) }\end{array}$ & $10(\mathrm{~L}) \quad 15(\mathrm{R})$ & $13(\mathrm{~L})$ & $132(\mathrm{R})$ \\
\hline Verbal IQ & $142(\mathrm{~L}) 138(\mathrm{R})$ & $\begin{array}{l}127.4(\mathrm{~L}) \\
(\mathrm{S} . \mathrm{E} . * 2=2.65)\end{array}$ & $\begin{array}{l}128.2(\mathrm{R}) \\
(\mathrm{S} . \mathrm{E} .=0.57)\end{array}$ \\
\hline Visuo-spatial IQ & $117(\mathrm{~L}) 130(\mathrm{R})$ & $\begin{array}{l}120.4(\mathrm{~L}) \\
(\mathrm{S} . \mathrm{E} .=2.61)\end{array}$ & $\begin{array}{l}120.7(\mathrm{R}) \\
(\mathrm{S} . \mathrm{E} .=0.78)\end{array}$ \\
\hline
\end{tabular}

* Standard error.

Both studies used the Wechsler Adult Intelligence Scale ${ }^{5}$.

My sample of left handed people is small but provides no evidence that there is any difference in IQ components between left and right handed people.

Neither of these investigations is on an adequate scale and both are on specialized samples. It therefore seems premature to reach any conclusions about relationships between IQ or IQ components and handedness.

\section{J. B. GIBSON}

Department of Genetics, University of Cambridge

Received April 24, 1973.

${ }^{1}$ Levy, J., Nature, 224, 614 (1969).

2 Levy, J, and Nagylaki, T., Genetics, 72, 117 (1972).

3 Miller, E., Brit. J. Psychol., 62, 111 (1971).

4 Gibson, J. B., and Light, P., Nature 213, 441 (1967)

5 Wechsler, D., Manual for the Wechsler Adult Intelligence Scale (The Psychological Corporation, New York, 1955). 